\title{
THE HISTORICAL ASPECT OF THE DETERMINATION \\ AND DEVELOPMENT OF VAT IN THE WORLD \\ AND THE PROBLEM OF ITS APPLICATION IN UKRAINE
}

\section{ІСТОРИЧНИЙ АСПЕКТ ВИНИКНЕННЯ \\ ТА ПОШИРЕННЯ ПДВ У СВІТІ ТА ОСОБЛИВОСТІ ЙОГО ЗАСТОСУВАННЯ В УКРАЇНІ}

\section{Belobrovenko Tatiana ${ }^{1}$}

DOI: http://dx.doi.org/10.30525/978-9934-571-28-2_3

\begin{abstract}
For Ukraine the VAT plays a significant budget forming role. However VAT potential in the modern tax system of Ukraine is realized not completely. For the first time, the value added tax was introduced in France in 1954. Then the VAT became widespread - first in other European countries, and later in the countries of Asia, Africa and Latin America. Today, VAT is levied more than in 140 countries. Such a scale of its application shows the acceptability and effectiveness of this tax to provide a reliable source of income for many governments. It should also be noted that the availability of VAT is a prerequisite for the admission of new members to the European Union. The purpose of the article is to study and generalize the historical aspects of the emergence and spread of VAT in the world, as well as the peculiarities of its application in Ukraine. Most countries in Europe and around the world have undergone a sufficiently long evolutionary path for the establishment and improvement of the VAT administration mechanism. From the analysis of the EU Directives on VAT, one can conclude that the EU does not stop at the achieved result, but continues to work towards harmonization and creation of a single VAT area. Of course, this process does not go without obstacles and certain problems, but the process of rebuilding and improving without them is impossible. The changes that may be made to the VAT administration mechanism in Ukraine, based on the analysis carried out, include an increase in the tax rate differentiation (this process has already started in Ukraine with the beginning of the $7 \%$ tax on medicines and medical equipment and equipment).
\end{abstract}

${ }^{1}$ Senior Assistant at Audit and Economic Analysis Department, University of State Tax Service of Ukraine, Ukraine 


\section{1. Ветуп}

У світовій практиці податок на додану вартість (ПДВ) вважається одним з найбільш ефективно працюючих податків, що стимулює національного виробника. Це непрямий бюджетоутворюючий податок. $\mathrm{У}$ другій половині $\mathrm{XX}$ століття в розвинених країнах світу його ввели, щоб обмежити перевиробництво.

Вперше податок на додану вартість було запроваджено у Франції в 1954 р. Потім ПДВ набув великого поширення - спочатку в інших країнах Європи, а пізніше - в країнах Азії, Африки та Латинської Америки. На сьогодні податок на додану вартість стягується більше, ніж у 140 країнах світу. Його розмір різниться від 5 до 28\%. 3 економічно розвинених країн ПДВ відсутній в США, довго не вводився в Швейцарії, Японії та Австралії, де діяв податок з продажу за ставкою від 2 до $11 \%$.

Також слід відмітити, що наявність ПДВ є обов'язковою умовою для вступу нових членів до Свропейського Союзу.

Метою статті є дослідження та узагальнення історичних аспектів виникнення та поширення ПДВ у світі, а також деякі особливості його застосування в Україні.

ПДВ як один із головних податків, на якому базується податкова система України, є предметом широких дискусій щодо доцільності його застосування та наслідків справляння для економічного розвитку і бюджету країни.

Деякі вітчизняні науковці та державні діячі вважають, що «діюча ставка ПДВ є дещо завищеною та наголошують на необхідності іiі зниження. I хоча зниження ставки податку має позитивне значення, оскільки воно буде сприяти збільшенню обсягів реалізації за рахунок зниження цін, що призведе до прискорення кругообігу фінансових ресурсів, що вкрай важливо для ефективного функціонування фінансової системи, все ж основні проблеми ПДВ полягають у невідпрацьованому механізмі його справляння» [1, с. 89].

Гострота дискусій щодо ПДВ у світі та в Україні викликана істотними побічними ефектами, з якими на практиці виявилось пов'язане запровадження найпривабливішої його риси - механізму відшкодування сум податку, сплачених у складі ціни товарів (робіт, послуг). Суми відшкодування з кожним роком зростають і досягли таких розмірів, що здатні впливати на інфляційні процеси в Україні. 


\section{2. Переваги та недоліки ПДВ}

Податок на додану вартість в Україні було запроваджено у 1992 році, і нині порядок розрахунків регулюється на підставі вимог Податкового кодексу України. Здавалося б за 26 років податкове законодавство України щодо ПДВ мало стати прозорим і досконалим.

Водночас тривожним фактом є те, що в дохідній частині бюджету збільшується частка податку на додану вартість. Це означає, що наша податкова система стає ще більш ПДВ-залежною. Уряд з кожним роком закладає ще більшу частку ПДВ у податкових надходженнях і робить таким чином нашу економіку ще більш залежною від одного податку як у дохідній, так і у видатковій частині.

Як свідчить моніторинг надходжень податків до бюджету у формуванні дохідної частини держбюджету України ПДВ належить 40-50\% [2]. Крім того, ПДВ становить третину від усіх надходжень державного бюджету і 9\% ВВП України. Компенсувати втрату такого джерела можна лише іншим споживчим податком. Ним міг би бути податок $з$ продажу. Але так як Україна поставила за мету вступ до Євросоюзу, то вона мусить врегулювати стабільні надходження з ПДВ, забезпечити повноту та прозорість адміністрування податку. Перш за все законодавство і практика цього податку мають відповідати його суті та призначенню.

Непрямі податки встановлюють в цінах товарів та послуг, їх розмір для окремого платника прямо не залежить від його доходів. Це так звані податки на споживання. Характеризуючи їх, Адам Сміт писав: «За відсутністю коштів для оподаткування підданих прямим податком, в розмірах отриманого ними доходу, уряд використав непрямі податки на їхні витрати, вважаючи, що витрати їхні в більшій частині випадків майже точно відповідають їхнім доходам» [3, с. 145].

Україна, яка розвивається із застосуванням зарубіжного досвіду, взяла за основу французьку модель ПДВ. На початку 90-х років цей податок був запроваджений для наповнення бюджету, тобто виконував і виконує по цей день яскраво виражену фіскальну функцію. На той час діяла ставка в розмірі $28 \%$, на сьогодні основна ставка становить 20\%, при цьому, Податковим кодексом України передбачається поступове іiі зниження до 17\% [4].

Головна особливість цього податку полягає в тому, що його платниками фактично є кінцеві споживачі товарів і послуг, причому як споживачі товарів і послуг виробничого призначення, так і споживачі това- 
рів і послуг особистого призначення. За допомогою цього податку між кінцевими споживачами рівномірно розподіляється та частина створеного в суспільстві продукту, яка має централізуватись і задовольняти загальнодержавні потреби. ПДВ стимулює економію витрат усіх видів матеріальних ресурсів, які не входять до складу собівартості продукції i, отже, не відшкодовуються підприємству, яке в такому разі виступає не як проміжний, а як кінцевий споживач (ряд витрат, не пов'язаних 3 веденням господарської діяльності, наприклад придбання основних засобів невиробничого призначення). У сфері обігу ПДВ стимулює продавців до стримування продажних цін на товари та послуги.

ПДВ має високу ефективність із фіскальної точки зору. Широка база оподаткування, яка включає не лише товари, але й роботи і послуги, забезпечує надійність та стабільність надходжень до бюджету. Універсальні ставки полегшують як обчислення податку для його платників, так і контроль органів ДФС за правильністю та своєчасністю його сплати. Стягнення ПДВ на всіх етапах руху товарів, робіт, послуг має наслідком рівномірний розподіл податкового тягаря між усіма суб'єктами господарювання.

Отже, по-перше, непрямим податкам (зокрема ПДВ) властиве швидке надходження. Перерахування податку у бюджет проводиться, як тільки відбулася реалізація. Крім того, фіскальна ефективність непрямих податків пов'язана з тим, що вони падають на широке коло предметів, тому сплачує їх величезна кількість населення, через що вони дають фіксований дохід, який важко одержати при прямому оподаткуванні.

По-друге, оскільки непрямими податками охоплюються товари народного споживання і послуги, то досить високою є ймовірність ïx повного чи майже повного надходження. Зупинити процес споживання ніхто не в змозі. А прибуток підприємство може і не одержати. Отже, споживання є надійним об'єктом оподаткування.

По-третє, непрямі податки менш помітні для споживачів, оскільки сплачуються шляхом включення їх до ціни товарів, що купуються. Крім того, сплачуються вони дрібними частками при придбанні кожної одиниці оподатковуваного товару, тому вони менш чутливі для платників, ніж прямі податки, де одразу вимагається сплата більш-менш значної суми. Нарешті, непомітність цих податків і в тому, що їх стягнення не пов'язане 3 неприємним для платника втручанням фіскальних органів 
у його приватне життя. Тому протидія непрямим податкам із сторони платників значно менша, ніж прямим.

Непрямі податки всеодно залишаються не помітнішими для платника, ніж прямі. Покупець при непрямому оподаткуванні не буде розраховувати, обчислювати, з'ясовувати розмір надбавки до ціни.

По-четверте, якщо платник ухиляється від сплати прямого податку, то це загрожує йому санкціями, а не придбавши того чи іншого товару, можна цілком легально ухилитися від сплати посереднього податку, особливо, коли цей товар є предметом не першої необхідності. Таким чином, споживач, збільшуючи або зменшуючи задоволення своїх потреб, сам регулює суму непрямих податків, яку він сплачує державі.

По-п'яте, якщо доходи бюджету базуються на доходах підприємств, то внаслідок нерівномірності економічного розвитку регіонів виникає проблема нерівномірності доходної бази різних бюджетів. Споживання ж більш рівномірне в територіальному розрізі, а тому застосування непрямих податків дає можливість збалансувати місцеві бюджети.

По-шосте, найкраща система прямих податків не може гарантувати того, що всі види прибутків справді будуть оподатковані. Ці види та частини прибутку, що вислизають від прямого оподаткування, якраз і можна захопити непрямим оподаткуванням. Крім того, лише воно дає змогу оподатковувати платника за його індивідуальною платоспроможністю.

По-сьоме, контроль за сплатою непрямих податків значно простіший, оскільки фіскальні органи мають справу з обмеженою групою платників непрямих податків, кількість яких порівняно 3 кількістю платників прямих податків досить незначна. Це пояснює значне поширення непрямих податків у ранніх податкових системах із низькою податковою технікою.

По-восьме, непрямі податки також справляють значний стимулюючий вплив і на саму державу, яка повинна забезпечити відповідні умови для розвитку виробництва і сфери послуг, адже чим більший обсяг реалізації в масштабі всієї економіки, тим більші надходження до бюджету.

ПДВ є могутнім фіскальним інструментом держави завдяки притаманним йому перевагам, а саме: простотою нарахування, зручністю сплати за місцем і часом, відсутністю примусового характеру, не вимагає накопичення певних сум. Цей податок визначається розміром 
споживання, тому виступає чинником, який стримує кризу перевиробництва і прискореного витіснення з ринку слабких виробників [5]. До недоліків ПДВ слід віднести значний його вплив на загальний рівень цін та регресивність, особливо щодо малозабезпечених верств населення. Встановлення нульових ставок на експортні товари створює позитивні передумови для збільшення обсягу експорту та підвищення конкурентоспроможності вітчизняних товарів на світовому ринку.

Якщо аналізувати ключові зміни, які прийняті у Податковому кодексі, то можна стверджувати, що в Україні законодавство передбачає необхідність гармонізації податкової системи $з$ європейськими стандартами, відтак ПДВ у Податковому кодексі був збережений. Дещо змінилося лише його адміністрування. Розробники Податкового кодексу намагалися вирішити комплекс завдань: перекрити найпоширеніші незаконні схеми мінімізації оподаткування, вирішити проблему з відшкодування ПДВ, а також знизити внутрішні ціни на зерно та металобрухт. Переваги та недоліки ПДВ наведені у табл. 1.

Таблиця 1

\section{Переваги та недоліки податку на додану вартість}

\begin{tabular}{|c|c|}
\hline Переваги ПДВ & Недоліки ПДВ \\
\hline $\begin{array}{l}\text { Відсутність подвійного оподатку- } \\
\text { вання і кумулятивного (каскадного) } \\
\text { ефекту }\end{array}$ & $\begin{array}{l}\text { Складний механізм нарахування та } \\
\text { сплати, прихована форма оподаткування } \\
\text { (платник-кінцевий споживач) }\end{array}$ \\
\hline $\begin{array}{l}\text { Платниками є всі учасники руху } \\
\text { товару від виробника до кінцевого } \\
\text { споживача }\end{array}$ & $\begin{array}{l}\text { Можливість ухилення від сплати } \\
\text { податку, в т.ч. за рахунок неузгоджено- } \\
\text { сті законодавчих актів з оподаткування, } \\
\text { недосконалої системи бухгалтерського } \\
\text { обліку та розрахунків за ПдВ }\end{array}$ \\
\hline $\begin{array}{l}\text { Як правило, рівні умови серед } \\
\text { виробників та продавців щодо } \\
\text { сплати податку }\end{array}$ & $\begin{array}{l}\text { Велика кількість пільг та операцій, звіль- } \\
\text { нених від оподаткування, через що ПДВ } \\
\text { виконує поряд з фіскальною функцією } \\
\text { регулюючу та стимулюючу }\end{array}$ \\
\hline $\begin{array}{l}\text { Ритмічність та стабільність податко- } \\
\text { вих надходжень }\end{array}$ & $\begin{array}{l}\text { При відсутності прозорої системи над- } \\
\text { ходжень до бюджету можлива наявність } \\
\text { бюджетної заборгованості, можливість } \\
\text { використання незаконних схем відшко- } \\
\text { дування ПДВ }\end{array}$ \\
\hline $\begin{array}{l}\text { Має широку базу оподаткування, } \\
\text { так як охоплює предмети широкого } \\
\text { вжитку і всі стадії руху продукції } \\
\end{array}$ & $\begin{array}{l}\text { Регресивний вплив, особливо на малоза- } \\
\text { безпечені верстви населення }\end{array}$ \\
\hline
\end{tabular}


Закінчення таблиці 1

\begin{tabular}{|l|l|}
\hline $\begin{array}{l}\text { Дає можливість стримувати } \\
\text { зростання цін }\end{array}$ & $\begin{array}{l}\text { Значні втрати бюджету від його мініміза- } \\
\text { ції та проблеми з відшкодуванням }\end{array}$ \\
\hline $\begin{array}{l}\text { Стримує кризу перевиробництва, } \\
\text { вирівнює можливість отримання } \\
\text { надприбутків та регулює процеси } \\
\text { споживання }\end{array}$ & $\begin{array}{l}\text { Негативно впливає на високотехноло- } \\
\text { гічні та науково місткі процеси }\end{array}$ \\
\hline $\begin{array}{l}\text { Збалансовує фіскальні потреби } \\
\text { уряду та необідність створення } \\
\text { умов для розвитку бізнесу }\end{array}$ & Фактор, що стимулює інфляцію \\
\hline $\begin{array}{l}\text { Податкове навантаження з ПДВ на } \\
\text { кінцевий товар не залежить від числа } \\
\text { оборотів і стадій створення вартості }\end{array}$ & \\
\hline
\end{tabular}

Джерело: узагальнено автором за даними [5]

Звісно, зваживши основні переваги та недоліки, можна стверджувати, що ПДВ має місце на існування та подальше удосконалення механізму його адміністрування.

\section{3. Виникнення та поширення ПДВ у світі}

На сьогодні ПДВ є прийнятим у більшості країн світу і на нього припадає близько $20 \%$ світового обсягу податкових надходжень. Майже наскрізне введення ПДВ вважається найважливішою подією в еволюції структури податків у першій половині ХХ ст.

ПДВ є досить молодим податком, так як більшість 3 нині діючих податків були введені в XIX столітті. Деякі з них, зокрема акцизи, земельний податок, відомі ще $з$ давніх часів, а ПДВ почали застосовувати лише в XX ст.

В міжнародній практиці непрямі податки позначаються як податки на споживання і включають три непрямі податки: податок на додану вартість, податок на продажі та податок з обороту.

Загалом момент запровадження ПДВ ніколи не був чітко визначений, оскільки існує два погляди на зародження даного податку:

ПДВ запропонований німецьким підприємцем В. фон Сіменсом у 1918 p.;

ПДВ розроблений американським економістом Т. Адамсом в його роботах у період між 1910 і 1921-1923 pp.

ПДВ в концепції В. фон Сіменса розглядався як технічна інновація, яка призвела до поліпшення функціонування основних податків. Він 
забезпечував повернення податків, які сплачувались за вхідні ресурси підприємства і тому дозволяв уникнути каскадної проблеми, яка виникала при використанні податку з обороту. У той час, як інновації явно були важливими, фон Сіменс не мав на увазі революційне повалення фінансового порядку [6, с. 15-16].

Т. Адамс запропонував ПДВ в якості альтернативи податку на доходи від підприємницької діяльності. Він був зосереджений на федеральній податковій політиці і, оскільки не було національного податку з продажів, його робота направлялася не на технічну модифікацію існуючого режиму, а грунтовну перебудову існуючої федеральної системи прибуткового податку. Німеччина, разом з більшістю країн Західної Європи, ввели ПДВ як зміну та удосконалення уже існуючого на той момент податку з продажу і як доповнення до податку на прибуток [6, с. 15-16].

В більшості наукових джерел першість щодо застосування ПДВ належить Франції. Точніше сказати ідея виникнення належить Німеччині, а практичне запровадження ПДВ відбулося у Франції. Це пояснюється тим, що ПДВ, який був там запроваджений найбільше схожий на сучасну модель даного податку. Кілька десятків років ПДВ існував винятково у вигляді ідеї, поки не було детально розписано механізм його дії та обгрунтовано переваги необхідності його застосування.

В основу механізму ПДВ покладено розвиток методології справляння та застосування податку з обороту, який пройшов послідовно три етапи. Перший етап ознаменований переходом в 1937 р. від податку з обороту до єдиного податку на виробництво. Другий - створенням в 1948 р. системи розподілених платежів, відповідно до якої кожен виробник платив податок з загальної суми своїх продажів за вирахуванням податку, що входив в ціну куплених ним комплектуючих, з різницею в один місяць. Третім етапом стало власне введення в податкову практику в 1954 р., як альтернатива єдиного податку на виробництво, ПДВ.

Тобто ПДВ прийшов як альтернатива на заміну інших непрямих податків, що не виправдали сподівань. Заміна податків є складним і тривалим процесом, з точки зору втрати частини доходів на початкових стадіях або економічної неефективності, або одразу того та іншого [6, с. 16].

Однією із перших форм непрямого оподаткування виявився податок 3 продажів, схожий за характером із ПДВ. Передумовою виникнення податку з продажів послужив гострий брак коштів у зв'язку з вели- 
чезними військовими витратами в період I Світової війни [7]. Даний податок стягувався багато разів на кожній стадії руху товару від виробника до споживача. Тому основним недоліком застосування податку 3 обороту був кумулятивний «каскадний ефект», який буквально можна розуміти як податок-на-податок. Даний податок створював ланцюг накопичених податків, що сплачувалися від першої стадії виробництва і до останнього етапу продажу. В результаті його функціонування ціна товару значно підвищувалась, що викликало величезне невдоволення як покупців, так і виробників. Перш за все, це було пов'язано з тим, що споживачі вимушені були купувати товари за досить завищеною ціною, яка витікала з багатократного оподаткування оборотів 3 продажів. 3 іншого боку, виробники зазнавали значних збитків унаслідок зниження попиту на свою продукцію. Це стало передумовою до того, що після I Світової війни неефективний та непопулярний податок був скасований у переважній більшості країн [8].

Першим досконало описав механізм дії ПДВ французький економіст Моріс Лоре у 1954 р. Він обгрунтував переваги ПДВ перед іншими універсальними акцизами - податком з обороту і податком з продажу. У 1967 р. ПДВ вперше запроваджується у Данії, 1968 р. - у Франції та Німеччині (ФРН), у 1969p. - у Нідерландах та Швеції.

Однак протягом більше десяти років ПДВ застосовувався в експериментальному варіанті, а дослідним полігоном для його застосування послужила залежна від Франції африканська держава Кот д’Вуар. Велика географія розповсюдження ПДВ свідчить про його життєздатність та відповідність вимогам ринкової економіки.

У Франції ПДВ у тому вигляді, який він має сьогодні, введений $з$ 1968p. з набуттям чинності Закону П’ятої Республіки № 66-10. Своєю метою Закон ставив: об'єднати, спростити і узагальнити порядок справляння ПДВ з тим, щоб перетворити його в єдиний і сучасний податок на виробничі витрати [8].

Наступним кроком у розповсюдженні ПДВ було підписання в Римі договору про створення Свропейського економічного співтовариства (СЕС) (1957р.), згідно з яким країни-учасниці повинні були гармонізувати свої податкові системи на користь створення спільного ринку, що поклало початок широкому розповсюдженню ПДВ в усьому світі.

В 1967 р. друга директива Ради СЕС проголосила ПДВ основним непрямим податком Свропи, зобов'язуючи всіх членів ЄЕС до 
1972 р. запровадити даний податок у свої податкові системи. Рада також висловила сподівання, що нова система призведе до зростання зовнішньої торгівлі, якій раніше перешкоджала складна та неефективна система податку з обороту. Після прийняття другої директиви, країни, що не входили в СЕС (Австрія, Греція, Швеція) внесли деякі зміни до системи адміністрування ПДВ, або як доповнення до вже існуючих податкових систем, або в якості заміни деяких податкових структур [9]. Роки запровадження ПДВ в деяких країнах світу наведені в табл. 2 [6, с. 16].

Таблиця 2

Хронологія запровадження ПДВ в різних країнах світу

\begin{tabular}{|l|c|l|}
\hline Країна запровадження ПДВ & Рік & \multicolumn{1}{|c|}{ Назва податку мовою країни } \\
\hline Франція & 1954 & TVA (Taxe sur la Valeur Ajoutée) \\
\hline Данія & 1967 & Moms (Merværdiafgift) \\
\hline Німеччина & 1968 & MwSt./USt. (Mehrwertsteuer) \\
\hline Нідерланди & 1969 & BTW (Belasting over de toegevoegde waarde) \\
\hline Швеція & 1969 & Moms (Mervärdesskatt) \\
\hline Великобританія & 1973 & VAT (Value Added Tax) \\
\hline Ізраїль & 1976 & Ma’am \\
\hline Австралія & 2000 & GST (Goods and Services Tax) \\
\hline Нова Зеландія & 1986 & GST (Goods and Services Taх) \\
\hline Канада & 1991 & GST (Goods and Services Тах) \\
\hline Україна & 1992 & ПДВ (Податок на додану вартість) \\
\hline Росія & 1992 & НДС (Налог на добавленную стоимость) \\
\hline Індія & 2005 & VAТ (Value Аdded Тах) \\
\hline
\end{tabular}

Джерело: узагальнено автором на основі [10, с. 280]

Шоста директива Ради СЕС, прийнята в 1977 р. остаточно затвердила базу сучасної європейської системи адміністрування ПДВ, чим сприяла уніфікації застосування його в Європі. Також уточнення в механізмі адміністрування ПДВ відбулись у 1991 р. через прийняття Десятої директиви СЕС, так як іiї положення були включені у податкове законодавство усіх країн-членів СЕС.

З 1987 по 1997 р. ПДВ був введений в багатьох країнах Східної Європи, країнах пострадянського простору, а також Азії. Бангладеш, Китай, Таїланд, Філіппіни, ввели ПДВ в середині 90-х рр. ХХ століття. 
Отже, ПДВ став одним з основних складових у податкових системах у більш ніж 140 країнах, з податковими ставками в діапазоні від 5 до 28\%.

Запровадження ПДВ також можна поділити на чотири умовні періоди, доцільно розглянути частку ПДВ у податкових надходженнях тих часів та частку у ВВП, щоб підкреслити значущість даного податку (табл. 3).

Значну частку (більше 20\%) у податкових надходженнях ПДВ займав на той час у Швеції, Данії, Великій Британії, Ірландії, Греції та Португалії. Найбільша частка ПДВ у ВВП належала таким країнам, як Швеція, Данія та Україна. Найбільшу початкову ставку ПДВ було введено в Україні, дещо менші в Франції та Норвегії.

Таблиця 3

Етапи введення ПДВ у світовій практиці

\begin{tabular}{|c|c|c|c|c|}
\hline $\begin{array}{c}\text { Період } \\
\text { введення } \\
\text { ПДВ }\end{array}$ & Країна & $\begin{array}{c}\text { Частка у } \\
\text { податкових } \\
\text { надходженнях, \% }\end{array}$ & $\begin{array}{l}\text { Частка у } \\
\text { ВВП, \% }\end{array}$ & $\begin{array}{r}\text { Стартова } \\
\text { ставка, \% }\end{array}$ \\
\hline \multirow{6}{*}{$\begin{array}{l}60-70 \text { pp. } \\
\text { ХХ ст. }\end{array}$} & Франція & 15,4 & 5,3 & 20 \\
\hline & Німеччина & 19,4 & 7,4 & 10 \\
\hline & Нідерланди & 18 & 6,9 & 12 \\
\hline & Швеція & 20,9 & 9,3 & 11,1 \\
\hline & Данія & 20,7 & 9,9 & 10 \\
\hline & Норвегія & 18,2 & 7,7 & 20 \\
\hline \multirow{6}{*}{$\begin{array}{l}70-80 \text { pp. } \\
\text { ХХ ст. }\end{array}$} & Австрія & 18,6 & 8 & 16 \\
\hline & Люксембург & 18,1 & 6,8 & 8 \\
\hline & Бельгія & 15,8 & 7,1 & 18 \\
\hline & Велика Британія & 20,9 & 7,4 & 10 \\
\hline & Ірландія & 21,6 & 6 & 16,4 \\
\hline & Італія & 13,7 & 6,1 & 12 \\
\hline \multirow{3}{*}{$\begin{array}{l}80-90 \text { pp. } \\
\text { ХХ ст. }\end{array}$} & Греція & 21 & 7,2 & 16 \\
\hline & Португалія & 26,1 & 8,5 & 16 \\
\hline & Іспанія & 16,6 & 5,4 & 12 \\
\hline \multirow{2}{*}{$\begin{array}{c}90 \text { рр. ХX ст.- } \\
\text { до XXI ст. }\end{array}$} & Швейцарія & 12,4 & 3,5 & 6,5 \\
\hline & Україна & 19,7 & 9,9 & 28 \\
\hline
\end{tabular}

Джерело: складено автором на основі [10, с. 281-282]

Також існує підхід, згідно якого прийняття ПДВ поділяється на два етапи. Перший етап мав місце в основному в Західній Європі і Латинській Америці у 1960-1970рр. Поширення ПДВ у Західній Європі при- 
скорилося прийняттям ряду Директив $\mathrm{CC}$, які вимагали від держав-членів введення гармонізованого ПДВ після вступу до ЄС. Другий етап впровадження ПДВ мав місце з кінця 1980-х рр. $з$ введенням ПДВ у деяких промислово-розвинутих країнах, що не входили в СС, таких як Австралія, Канада, Японія та Швейцарія. Цей етап також характеризується широким поширенням ПДВ в країнах з перехідною економікою $\mathrm{i}$ країнах, що розвиваються, особливо в країнах Африки та Азії [9].

На основі дослідження підходів до поділу історії становлення та розвитку ПДВ, можемо виділити такі етапи: перший етап (1910 1953 рр.) - виникнення ідеї застосування ПДВ, доведення його переваг в порівнянні з подібними податками; другий етап (1954 - 1966 рр.) введення ПДВ у практику країн Свропейського економічного співтовариства; третій етап (1967 - 1990 рр.) - впровадження ПДВ у країнах Західної та Центральної Європи, Латинської Америки у деяких промислово-розвинутих країнах, що не входили в СС, таких як Австралія, Канада, Японія та Швейцарія в країнах з перехідною економікою і країнах, що розвиваються, особливо в країнах Африки та Азії; четвертий етап (1990 - 2000 рр.) - поширення ПДВ у країнах Східної Свропи, Азії, Австралії, Африки; п'ятий етап (починаючи 32001 р. до сьогодні) - гармонізація та уніфікація законодавства з ПДВ у країнах-членах $Є С$ та подальше удосконалення механізму адміністрування ПДВ у інших країнах світу.

I хоча ПДВ набув широкого поширення у світовій практиці, його часто називають «європейським податком», віддаючи належне країнам появи даного податку, так і ролі ПДВ у становленні та розвитку західноєвропейського, а надалі загальноєвропейського інтеграційного процесу.

ПДВ є важливим джерелом бюджетної бази Свропейського співтовариства: кожна країна-учасниця ЄС перераховує 1\% надходжень від податку в «європейський» бюджет [11].

Гармонізація непрямого оподаткування, особливо ПДВ є важливим етапом для наближення законодавства України з законодавством країн-членів СС. Даний процес повинен проводитися системно, враховуючи усі сторони, переваги та недоліки, що дозволить уникнути неузгодженостей при внесенні змін та доповнень до діючих нормативно-правових актів України.

Процес гармонізації системи непрямого оподаткування ЄС, загалом, та ПДВ, зокрема, у країнах Свропи пройшов певні етапи, а саме: 


\section{Belobrovenko Tatiana}

Римський договір про створення ЄС (1957 р.): встановлював принципи створення Свропейського економічного співтовариства (СЕС), а також основи гармонізації податку з обороту країн-членів, з метою оптимізації роботи загального ринку;

Перша Директива СС по ПДВ (1967р.): встановила вимоги до країн-учасниць, щодо заміни податку з обороту ПДВ;

Друга Директива по ПДВ (1967р.): визначила більш-менш точні правила із введення ПДВ країнами-членами $\mathrm{CEC}$;

Шоста Директива по ПДВ (1977р.): скасувала дію Другої Директиви та частково Першої. Нові правила зазначені в даній Директиві врегулювали важливі питання: територіальну дію, операції, які підлягали оподаткуванню, види ставок, пільги, визначення платника податків, бази оподаткування та місця здійснення операції. Окремі вимоги стосувались лише малого підприємництва та земле володільців;

перехідна Директива (1993р.): скасовувала податкові бар'єри торгівлі між країнами-членами СС, встановлено єдині вимоги до країн, щодо впровадження законодавства з ПДВ та механізму його адміністрування. Особливу увагу було приділено механізму відшкодування ПДВ при здійсненні операцій із партнерами, що розташовані за межами території Співтовариства, запровадженню ідентифікаційних номерів, визначенню вимог щодо оформлення та збереження податкової документації;

Директива по електронному підприємництву (2002р.): визначено порядок розрахунку ПДВ при наданні електронних послуг країнами-членами СС покупцям з інших країн та навпаки. Місцем надання таких послуг є місце розташування покупця;

перероблена Шоста Директива (2006 р.): врахувала значну кількість поправок, що вносились від часу прийняття попередньої Шостої Директиви;

пакет Директив по ПДВ (2007р.): вводиться з метою спрощення та удосконалення системи ПДВ для міжнародної торгівлі і для боротьби 3 шахрайством. Даний пакет включає в себе такі зміни: нові правила, щодо визначення місця надання послуг (реалізація послуг обкладаєТься ПДВ саме в країні місцезнаходження замовника за принципом «зворотного оподаткування»), введення обов'язкової Зведеної Свропейської Декларації (Obligatory European Sales List (ESL)), в якій зазначаються міжнародні послуги і зміни до ESL щодо товарів, нова проце- 
дура відшкодування ПДВ, що здійснюється в електронній формі, щодо податку сплаченого в інших державах-членах СС. Правило «зворотного оподаткування» застосовується до замовників, які є платниками податків (Business to Business або В2B) та випадків, якщо послуги надає оподатковувана особа неоподатковуваній особі (Business to Consumer або В2С). В останньому випадку правило залишилося колишнім: місцем надання послуг є місцезнаходження постачальника послуг [12].

Ставки ПДВ в СС встановлюються кожною країною самостійно (табл. 4). Законодавством СС не визначаються ставки, а лише мінімальний розмір основної (стандартної) ставки [12].

На ряд пільгових товарів передбачено застосування зниженої ставки, які не повинні бути нижчими ніж 5 \%. Країни-члени СС можуть використовувати знижену ставку, щодо операцій із постачання природного газу, електрики та централізованого теплопостачання.

Таблиця 4

Ставки ПДВ в країнах ЄС

\begin{tabular}{|c|c|c|c|}
\hline \multirow{2}{*}{ Країна } & \multicolumn{2}{|r|}{ Ставка } & \multirow{2}{*}{ Абревіатура } \\
\hline & Стандартна & Знижена & \\
\hline 1 & 2 & 3 & 4 \\
\hline Австрія & $20 \%$ & $12 \%$ або $10 \%$ & USt. \\
\hline Бельгія & $21 \%$ & $12 \%$ або 6\% & BTW/TVA/MWSt \\
\hline Болгарія & $20 \%$ & $9 \%$ & DDS = ДДС \\
\hline Велика Британія & $20 \%$ & $5 \%$ або $0 \%$ & VAT \\
\hline Данія & $25 \%$ & & moms \\
\hline Німеччина & $19 \%$ & $7 \%$ & MwSt./USt. \\
\hline Греція & $23 \%$ & \begin{tabular}{|l}
$13 \%$ або $6,5 \%$ (зниже- \\
ний на $30 \%$ до $13 \%$, \\
$6 \%$ і $3 \%$ на островах) \\
\end{tabular} & ФПА \\
\hline Ірландія & $21 \%$ & $13.5 \%, 4,8 \%$ або $0 \%$ & $\begin{array}{l}\text { CBL } \\
\text { VAT }\end{array}$ \\
\hline Іспанія & $18 \%$ & $8 \%$ або 4\% & IVA \\
\hline Італія & $22 \%$ & $10 \%, 6 \%$, або 4\% & IVA \\
\hline Кіпр & $15 \%$ & $5 \%$ & ФПА \\
\hline Латвія & $22 \%$ & $12 \%$ & PVN \\
\hline Литва & $21 \% 0^{[4]}$ & 9\% або 5\% & PVM \\
\hline Люксембург & $15 \%$ & $12 \%, 9 \%, 6 \%$, або $3 \%$ & TVA \\
\hline Мальта & $18 \%$ & $5 \%$ & TVM \\
\hline
\end{tabular}


Belobrovenko Tatiana

Закінчення таблиці 4

\begin{tabular}{|l|l|l|l|}
\hline \multicolumn{1}{|c|}{1} & \multicolumn{1}{c|}{3} & \multicolumn{1}{c|}{4} \\
\hline Нідерланди & $21 \%$ & $6 \%$ або $0 \%$ & BTW \\
\hline Польща & $23 \%$ & $8 \%, 5 \%$ або $0 \%$ & PTU/VAT \\
\hline Португалія & $23 \%$ & $13 \%$ або $6 \%$ & IVA \\
\hline Румунія & $19 \%$ & $9 \%$ & TVA \\
\hline Словаччина & $20 \%$ & - & DPH \\
\hline Словенія & $20 \%$ & $8.5 \%$ & DDV \\
\hline Угорщина & $27 \%$ & $18 \%, 5 \%$ & ÁFA \\
\hline Фінляндія & $22 \%$ & $17 \%$ або $8 \%$ & ALV/ Moms \\
\hline Франція & $20 \%$ & $5.5 \%$ або $2,1 \%$ & TVA \\
\hline Швеція & $25 \%$ & $12 \%$ або 6\% & Moms \\
\hline Чехія & $21 \%$ & $10 \%$ & DPH \\
\hline Естонія & $18 \%$ & $5 \%$ & $\mathrm{~km}$ \\
\hline
\end{tabular}

Джерело: складено автором

При застосуванні ПДВ перед країнами-членами СС виникла проблема, щодо оподаткування операцій всередині $\mathrm{CC}$, оскільки ставки у країнах значно відрізнялися і відрізняються. Окрім того, оскільки митне оформлення товарообороту припинялося, то все адміністрування ПДВ-ланцюга ставало дещо проблематичним. Фактично СС був змушений вирішувати, яким чином справляння ПДВ на регіональному рівні. Для вирішення цієї проблеми було прийнято рішення не оподатковувати експортно-імпортні операції між країнами-членами, а нараховувати ПДВ у бюджет тієї країни, в якій відбувся продаж кінцевому споживачеві (рис. 1). Таке виключення застосовується лише щодо

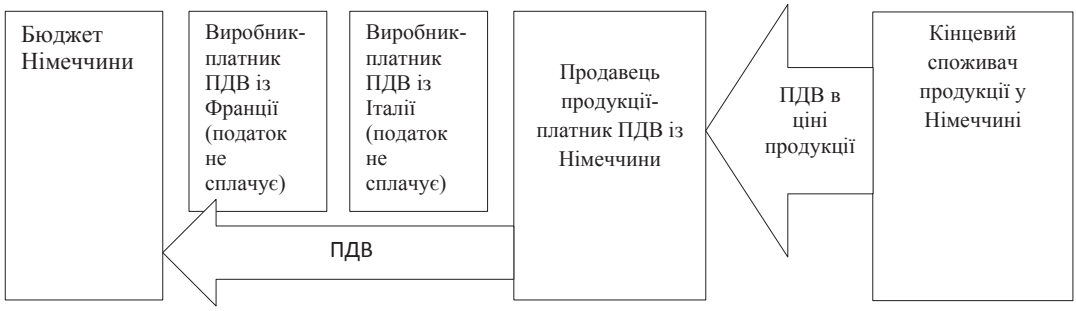

Рис. 1. Умовна схема адміністрування ПДВ у СС при експортно-імпортних операціях між країнами-членами $\mathbf{C C}$ Джерело: складено автором за даними [13, с. 11] 
The historical aspect of the determination and development of VAT in the...

операцій між країнами-членами, всередині країни-члена ЄС операції оподатковуються та обліковуються за стандартною процедурою 3 наявністю податкового кредиту з ПДВ та сплатою ПДВ до бюджету на кожному етапі виробництва чи реалізації продукції.

Щодо інших країн, то їх стандартні та знижені ставки можна дослідити в таблиці 5.

Таблиця 5

Ставки ПДВ в інших країнах світу, що не входять до ЄС

\begin{tabular}{|c|c|c|}
\hline \multirow{2}{*}{ Країна } & \multicolumn{2}{|c|}{ Ставка } \\
\hline & Стандартна & Знижена \\
\hline Австралія & $10 \%$ & $0 \%$ \\
\hline Аргентина & $21 \%$ & $10.5 \%$ або $0 \%$ \\
\hline Білорусь & $20 \%$ & - \\
\hline Боснія і Герцеговина & $17 \%$ & - \\
\hline Венесуела & $11 \%$ & $8 \%$ \\
\hline В'єтнам & $10 \%$ & $5 \%$ або $0 \%$ \\
\hline Ісландія & $24.5 \%$ & $14 \%^{3}$ \\
\hline Індія & $12.5 \%$ & $4 \%, 1 \%$, або $0 \%$ \\
\hline Ізраїль & $15.5 \%$ & - \\
\hline Казахстан & $13 \%$ & - \\
\hline Канада & $6 \%$ або $14 \%$ & $4.5 \%$ \\
\hline КНР & $17 \%$ & $6 \%$ або $3 \%$ \\
\hline Мексика & $16 \%$ & $0 \%$ \\
\hline Молдова & $20 \%$ & $5 \%$ \\
\hline Норвегія & $25 \%$ & $14 \%$ або $8 \%$ \\
\hline Парагвай & $10 \%$ & $5 \%$ \\
\hline Росія & $18 \%$ & $10 \%$ або $0 \%$ \\
\hline Сербія & $18 \%$ & $8 \%$ або $0 \%$ \\
\hline Таїланд & $7 \%$ & - \\
\hline Туреччина & $18 \%$ & $8 \%$ або $1 \%$ \\
\hline Україна & $20 \%$ & $7 \%$ або $0 \%$ \\
\hline Уругвай & $23 \%$ & $14 \%$ \\
\hline Філіппіни & $12 \%$ & - \\
\hline Хорватія & $22 \%$ & $0 \%$ \\
\hline Чилі & $19 \%$ & - \\
\hline Швейцарія & $7.6 \%$ & $3.6 \%$ або $2,4 \%$ \\
\hline Японія & $8 \%$ & - \\
\hline
\end{tabular}

Джерело: складено автором 


\section{Belobrovenko Tatiana}

\section{4. Пропозиції}

Без сумніву, досвід європейських країн повинен використовуватися при реформуванні української податкової системи в частині ПДВ із врахування особливостей, рівня розвитку та готовності вітчизняної економіки.

Дослідивши зарубіжний досвід застосування ПДВ, можна зробити висновок, що основними причинами зниження фіскального потенціалу ПДВ в Україні є: тіньовий сектор економіки; незаконні схеми відшкодування ПДВ; використання недиференційованих ставок ПДВ, що $\epsilon$ соціально несправедливим явищем.

Зазначимо, що переважна частина пільг з ПДВ формується за рахунок нульової ставки ПДВ та господарських операцій, звільнених від оподаткування, тобто наявна широка база податкових пільг та операцій, по яким не передбачена сплата цього податку, в той час як пільги соціального спрямування не набули поширення. Використання єдиної ставки ПДВ, зумовлює його регресивність і соціальну несправедливість, адже в структурі витрат бідніших верств населення частка ПДВ $\epsilon$ вищою, ніж у доходах заможних громадян. Такий недолік податку може бути подоланий диференціацією ставок щодо різних груп товарів або зниженням існуючої ставки ПДВ.

Слушною є думка науковців про те, що сьогодні виникає необхідність зміни розмірів ставок ПДВ у бік зниження або диференціації. 3 метою зменшення диференціації рівня життя громадян ставки непрямих податків, в тому числі і ПДВ, доцільно встановлювати диференційовані: використовувати занижені ставки для товарів, які включені до мінімального споживчого кошика, і завищені - для предметів розкоші. Ми пропонуємо, використовуючи досвід зарубіжних країн, запровадити в Україні диференційовані ставки ПДВ (табл. 6), адже використання цих ставок забезпечить регулюючу функцію та функцію соціальної справедливості податку.

Крім того не слід забувати, про регулюючу функцію ПДВ. Щоб підвищити ступінь ділової активності економіки України в цілому, податкове навантаження з ПДВ треба послабити.

Якщо зменшити основну ставку податку та ввести кілька пільгових, то у суб'єктів господарювання можуть з'явитися додаткові стимули для збільшення обсягів виробництва. Таким чином розшириться база оподаткування, і зросте загальна сума доходів зведеного бюджету. Також через зниження ставок ПДВ зросте сукупний попит населення. 
Запропонована диференціація ставок ПДВ

в залежності від категорії товарів

\begin{tabular}{|c|c|}
\hline Категорія товару & Ставка ПДВ, \% \\
\hline $\begin{array}{l}\text { Основні види продукції зі стабільним } \\
\text { попитом }\end{array}$ & $\begin{array}{l}\text { Основна ставка - } 20 \text { і поступове змен- } \\
\text { шення її до } 17, \text { як це передбачено ПК }\end{array}$ \\
\hline $\begin{array}{l}\text { Предмети розкоші, підакцизні та } \\
\text { імпортні товари }\end{array}$ & Підвищена - 20, 25 \\
\hline $\begin{array}{l}\text { Продукція на експорт, продукти хар- } \\
\text { чування, ліки, дитячий одяг та взуття, } \\
\text { дитяче харчування, товари щоденного } \\
\text { попиту та першої необхідності }\end{array}$ & Пільгові ставки - 0;7;10 \\
\hline
\end{tabular}

Джерело: складено автором

Знижені ставки доцільно застосовувати під час реалізації деяких товарів вітчизняного виробництва: продукти харчування, ліки, дитячий одяг та взуття, дитяче харчування, товари щоденного попиту та першої необхідності та товари, призначені на експорт.

Що стосується підвищених ставок, то, наприклад, обороти з реалізації підакцизної продукції вітчизняного виробництва можна оподатковувати ПДВ за ставкою 20 \%, а іноземного виробництва - за ставкою 25 \%. Вибір підакцизної та імпортної продукції як бази оподаткування підвищеними ставками ПДВ дозволить максимально реалізувати регулюючу функцію цього податку шляхом обмеження споживання імпортної та шкідливої для здоров'я продукції та шляхом підтримки вітчизняного виробника та застосування підвищених ставок до заможних громадян, які можуть собі дозволити предмети розкоші. Це в свою чергу забезпечить прогресивний характер ПДВ, тобто, хто більше заробляє, більше і сплачує.

\section{5. Висновки}

Більшість країн Європи та всього світу пройшли достатньо довгий еволюційний шлях становлення та удосконалення механізму адміністрування ПДВ. 3 аналізу Директив СС, щодо ПДВ, можна зробити висновок, що ЄС не зупиняється на досягнутому результаті, а продовжує роботу у напрямі гармонізації та уніфікації ПДВ. Звісно, що даний процес не проходить без перешкод та певних проблем, але процес перебудови та удосконалення без них неможливий.

До змін, що можуть бути внесені в механізм адміністрування ПДВ в Україні, на основі проведеного дослідження, належить 


\section{Belobrovenko Tatiana}

поглиблення диференціації ставки ПДВ (даний процес уже розпочався в Україні із початком використання 7 \% податку щодо ліків та медичних препаратів та медичного приладдя згідно переліку, затвердженого КМУ).

\section{Список літератури:}

1. Тулуш Л.Д. Сутність і роль податку на додану вартість в економічній системі держави // Економіка АПК. - 2008. - N 12. - С. 85-89.

2. Анализ фискальной эффективности НДС в Украине [Електронний pecypc] / сайт Экономика и финансы - Режим доступу до ресурсу : http://portfinance.ru/ukraine-1.html.

3. Смит А. Исследование о природе и причинах богатства народов. Т.1. М.: Соцэгиз, 1935. $-256 \mathrm{c}$.

4. Податковий кодекс України № 2755-VI від 02 грудня 2010 року [Електронний ресурс] / сайт Верховної ради України - Режим доступу до pecypcy : http://zakon4.rada.gov.ua/laws/show/2755-17.

5. Семенко Т. М. Податковий і фінансовий облік ПДВ згідно Податкового кодексу України / Т. М. Семенко [Електронний ресурс]. - Режим доступу: http://www.nbuv.gov.ua/portal/Soc_Gum/Oif_apk/2011_2/12_Semen.pdf

6. James K. Exploring the origins and global rise of VĀT / K. James // Tax Analyst. - 2011. - № 2. - P. 15-22.

7. Бровенко М. О. Удосконалення системи непрямого оподаткування в сучасних умовах розвитку економіки [Електронний ресурс] / М. О. Бровенко, C. А. Клімовська - Режим доступу до ресурсу : http://www.rusnauka.com/29 DWS 2009/Economics/53718. doc.Htm

8. Tuan Minh Le. Value Added Taxation: Mechanism, Design, and Policy Issues [Електронний ресурс] / Tuan Minh Le // Washington D.C. - 2003. - Режим доступу до ресурсу : http://www1.worldbank.org/publicsector/LearningProgram/ PracticalIssues/papers/Value20added\%20taxation/Value\%20Added\%20Taxation.doc.

9. Value added tax [Електронний ресурс] / сайт Reference for business Режим доступу до ресурсу : http://www.referenceforbusiness.com/management/ TrZ/Value-Added-Tax.html.

10. Worldwide VAT, GST and Sales tax guide 2014 // Ernst and Young. 2014. - P. 279-292.

11. Study to quantify and analyse the VAT gap in the EU-27 Member States Final report [Електронний pecypc] / European Commission - Режим доступу до ресурсу: http://ec.europa.eu/taxation_customs/resources/documents/common/ publicats/studies/vat-gap.pdf.

12. VAT: Overview of EU legislation [Електронний ресурс] / European Commission - Режим доступу до pecyрсу : http://ec.europa.eu/taxation_customs/ taxation/vat/how_vat_works/index_en.htm\#vat_overview.

13. Боярчук Д. Ц Цікаві факти про ПДВ / Д. Боярчук // Популярна економіка: ціна держави. - 2014. - № 26. - С. 1-13. 


\section{References:}

1. Tulush L.D. (2008) Sutnist' i rol' podatku na dodanu vartist' $v$ ekonomichniy systemi derzhavy [The essence and role of the value added tax in the economic system of the state]. Ekonomika APK., no 12, pp. 85-89.

2. Analyz fyskal'noy éffektyvnosty NDS $v$ Ukrayne [Analysis of fiscal efficiency of VAT in Ukraine]. site Economy and finance. Retrieved from: http://portfinance.ru/ukraine-1.html. (accessed 10 January 2018).

3. Smyt A. (1935) Yssledovanye o pryrode y prychynakh bohat•stva narodov [Study on the nature and causes of wealth of peoples] no.1, Moscow: Sotséhyz, $256 \mathrm{pp}$.

4. Podatkovyy kodeks Ukrayiny no. 2755-VI vid 02 hrudnya 2010 roku [Tax Code of Ukraine] sayt Verkhovnoyi rady Ukrayiny. Retrieved from: http://zakon4.rada.gov.ua/laws/show/2755-17 (accessed 10 January 2018).

5. Semenko T. M. Podatkovyy i finansovyy oblik PDV z $\bullet$ hidno Podatkovoho kodeksu Ukrayiny [Tax and financial accounting of VAT according to the Tax Code of Ukraine]. Retrieved from: http://www.nbuv.gov.ua/portal/Soc_Gum/Oif_ apk/2011_2/12_Semen.pdf (accessed 10 January 2018).

6. James $\overline{\mathrm{K}}$. Exploring the origins and global rise of VAT / K. James // Tax Analyst. - 2011. - № 2. - P. 15-22.

7. Brovenko M. O., S. A. Klimovska (2009) Udoskonalennya systemy nepryamoho opodatkuvannya $\mathrm{v}$ suchasnykh umovakh rozvytku ekonomiky [Improvement of the system of indirect taxation in the current conditions of economic development] / Retrieved from:: http://www.rusnauka.com/29 DWS_2009/Economics/53718. doc.Htm (accessed 10 January 2018).

8. Tuan Minh Le. Value Added Taxation: Mechanism, Design, and Policy Issues [Electronic resource] / Tuan Minh Le // Washington D.C. - 2003. - Retrieved from:: http://wwwl.worldbank.org/publicsector/LearningProgram/PracticalIssues/ papers/Value20added\%20taxation/Value\%20Added\%20Taxation.doc.

9. Value added tax [Electronic resource] / сайт Reference for business - Retrieved from:: http://www.referenceforbusiness.com/management/TrZ/Value-Added-Tax.html.

10. Worldwide VAT, GST and Sales tax guide 2014 // Ernst and Young. 2014. - P. 279-292.

11. Study to quantify and analyse the VAT gap in the EU-27 Member States Final report [Electronic resource] / European Commission. Retrieved from: http://ec.europa.eu/taxation_customs/resources/documents/common/publicats/ studies/vat-gap.pdf.

12. VAT: Overview of EU legislation [Electronic resource] / European Commission - Retrieved from: http://ec.europa.eu/taxation_customs/taxation/vat/ how vat works/index en.htm\#vat overview.

13. Boyarchuk D. (2014)Tsikavi fakty pro PDV [nteresting Facts About VAT] Populyarna ekonomika : tsina derzhavy, no. 26, pp. 1-13. 